Web Jurnal:

http://ejournal.kemenperin.go.id/jli

\title{
Transesterifikasi minyak kemiri sunan menjadi biodiesel menggunakan katalis padat $\mathrm{K}_{2} \mathrm{O} / \mathrm{C}$
}

\section{Transesterification of Reutealis trisperma oil into biodiesel over $\mathrm{K}_{2} \mathrm{O} / \mathrm{C}$ solid catalyst}

\author{
Muhammad Zaki*1, Teku Muhammad Asnawi ${ }^{1}$, Husni Husin ${ }^{1,2}$, Saifullah Ramli ${ }^{1}$, Sofyana ${ }^{1}$, Fikri Hasfita ${ }^{3}$ \\ Justaman Arifin Karo Karo ${ }^{4}$ \\ 1 Laboratorium Teknik Reaksi dan Katalisis, Jurusan Teknik Kimia, Fakultas Teknik, Universitas \\ Syiah Kuala, Darussalam-Banda Aceh, Indonesia 23111 \\ 2 Doktor Ilmu Teknik, Program Pascasarjana, Universitas Syiah Kuala, Darussalam-Banda Aceh, \\ Indonesia 23111 \\ 3 Jurusan Teknik Kimia, Fakultas Teknik, Universitas Malikussaleh, Lhokseumawe, Indonesia \\ 4 Baristand Industri Medan, Badan Penelitian dan Pengembangan Industri, Kementerian \\ Perindustrian, Medan, Indonesia \\ * e-mail:m.zaki@che.unsyiah.ac.id
}

\begin{tabular}{l}
\hline INFO ARTIKEL \\
\hline Sejarah artikel: \\
Diterima: \\
24 April 2020 \\
Direvisi: \\
28 November 2020 \\
Diterbitkan: \\
28 Desember 2020
\end{tabular}

\section{Kata kunci:}

katalis padat $\mathrm{K}_{2} \mathrm{O} / \mathrm{C}$; minyak kemiri sunan; kalium oksida; karbon aktif; biodiesel

\begin{abstract}
ABSTRAK
Preparasi katalis padat $\mathrm{K}_{2} \mathrm{O} / \mathrm{C}$ telah berhasil disiapkan dengan mengimpregnasi $\mathrm{K}_{2} \mathrm{CO}_{3}$ pada permukaan karbon aktif sekam padi selama 6 jam. Campuran tersebut dikalsinasi pada suhu $300{ }^{\circ} \mathrm{C}$ selama 3 jam hingga terbentuk $\mathrm{K}_{2} \mathrm{O} / \mathrm{C}$. Tujuan penelitian ini adalah untuk menginvestigasi kinerja katalis $\mathrm{K}_{2} \mathrm{O} / \mathrm{C}$ dalam proses transesterifikasi minyak biji kemiri sunan menjadi biodiesel. Karbon sekam padi (C) dipersiapkan dengan proses pirolisis sekam padi, dilanjutkan dengan proses aktivasi untuk mendapatkan karbon sebagai penyangga berpori. Katalis $\mathrm{K}_{2} \mathrm{O} / \mathrm{C}$ dikarakterisasi dengan Scanning Electron Microscopy (SEM) dan Energy-Dispersive X-ray (EDX). Hasil analisa EDX menunjukkan bahwa komposisi katalis didominasi oleh karbon (C) dan kalium (K). Fasa aktif $\mathrm{K}_{2} \mathrm{O}$ terdistribusi pada permukaan karbon aktif secara merata. Katalis $\mathrm{K}_{2} \mathrm{O} / \mathrm{C}$ yang dihasilkan digunakan dalam reaksi transesterifikasi minyak kemiri sunan menggunakan reaktor batch. Yield biodiesel tertinggi dicapai hingga 98,68\% ketika menggunakan katalis $4 \%$ terhadap minyak, loading $\mathrm{K}_{2} \mathrm{CO}_{3}$ pada karbon aktif $0,5 \%$ berat, waktu reaksi 90 menit, serta rasio molar metanol terhadap minyak $8: 1$. Katalis $\mathrm{K}_{2} \mathrm{O} / \mathrm{C}$ sangat berpotensi untuk dikembangkan selanjutnya sebagai salah satu katalis padat untuk mengkonversi minyak nabati menjadi biodiesel.
\end{abstract}

Keywords:

solid catalyst;

Reutealis trisperma

oil;

potassium oxide; activated carbon; biodiesel

\begin{abstract}
$\mathrm{K}_{2} \mathrm{O} / \mathrm{C}$ solid catalysts were succesfully prepared by impregnating $\mathrm{K}_{2} \mathrm{CO}_{3}$ on the surface of rice husk activated carbon. The mixture was calcined at $300{ }^{\circ} \mathrm{C}$ for 3 hours to produce $\mathrm{K}_{2} \mathrm{O} / \mathrm{C}$. The purpose of this study was to investigate the performance of the $\mathrm{K}_{2} \mathrm{O} / \mathrm{C}$ catalyst through the transesterification of Reutealis trisperma oil into biodiesel. The activated carbon was prepared by pyrolysis of rice husk, followed by activation process to obtain porous activated carbon. $\mathrm{K}_{2} \mathrm{O} / \mathrm{C}$ catalysts were characterized by scanning electron microscopy (SEM) and Energy-dispersive X-ray (EDX). The composition of the catalyst is dominated by carbon $(C)$ and potassium $(K)$. The active phase of $\mathrm{K}_{2} \mathrm{O}$ was evenly distributed over the surface of activated carbon. $\mathrm{K}_{2} \mathrm{O} / \mathrm{C}$ catalyst was used in the transesterification reaction of Reutealis trisperma oil in a batch reactor. The highest yield of biodiesel reached up to $98.68 \%$, at a $\mathrm{K}_{2} \mathrm{CO}_{3}$ of 0.5 , using $4 \%$ catalyst to oil, reaction temperature of $65{ }^{\circ} \mathrm{C}, 90$ minutes, and methanol to oil ratio of $8: 1 . \mathrm{K}_{2} \mathrm{O} / \mathrm{C}$ catalyst has a high potential to be further developed as one of promising solid catalysts in conversion of vegetable oil into biodiesel.
\end{abstract}




\section{Pendahuluan}

Seiring dengan kekurangan sumber bahan bakar dan meningkatnya emisi polutan yang disebabkan oleh pembakaran bahan bakar fosil, banyak penelitian telah diarahkan pada eksploitasi bahan bakar alternatif terbarukan (Boonyuen et al., 2018; Husin et al., 2018b). Di antara berbagai bahan bakar alternatif, biofuel (khususnya biofuel cair misalnya, bioetanol, biobutanol dan biodiesel), telah banyak menarik perhatian para peneliti sebagai bahan bakar yang paling prospektif untuk aplikasi di sektor transportasi (Abedin et al., 2016; Aboelazayem et al., 2018; Husin et al., 2018a; Husin et al., 2013). Hal ini karena sumber energi biofuel mampu menyalakan mesin dengan mudah dan jauh lebih sedikit mengeluarkan emisi berbahaya seperti: SOx, HC, dan $\mathrm{CO}$ dibandingkan dengan bahan bakar fosil (Abdullah et al., 2017; Aboelazayem et al., 2018; Farooq et al., 2018).

Biodiesel, sebagai sumber energi alternatif yang potensial, telah menarik perhatian besar dalam beberapa tahun terakhir (Akinfalabi et al., 2017; Ong et al., 2019). Namun, tingginya biaya produksi biodiesel dibandingkan dengan bahan bakar diesel yang berbasis minyak bumi masih membatasi pengembangannya. Penggunaan jenis katalis dan proses yang digunakan memberi kontribusi terhadap tingginya biaya produksi reaksi transesterifikasi (Granados et al., 2007; Zuhra et al., 2015). Proses pembuatan biodiesel saat ini umumnya menggunakan katalis basa kuat homogen atau asam kuat karena memiliki aktivitas dan konversi yang tinggi. Kekurangan dari proses homogen antara lain: pemisahan katalis dan pemurnian produk lebih lama dan menghasilkan limbah cair yang lebih banyak. Hal ini tentunya membutuhkan biaya produksi yang lebih tinggi (Borges and Díaz, 2012). Untuk mengurangi produksi limbah cair dan biaya produksi dari proses homogen, penelitian ini menggunakan katalis padat sistem heterogen (Sy et al., 2019). Keuntungan penggunaan proses heterogen, antara lain: katalis dapat dipisahkan lebih mudah dari campuran reaksi dengan cara penyaringan atau sentrifugasi. Disamping itu, katalis padat juga dapat digunakan kembali untuk beberapa kali proses reaksi. Selain itu, katalis ini kurang korosif, lebih aman, dan lebih ramah lingkungan (Islam et al., 2015).

Pada skala laboratorium, beberapa katalis heterogen, seperti $\mathrm{CaO}$ dari cangkang kerang, $\mathrm{K}_{2} \mathrm{O}$ /zeolite, dan Naloaded $\mathrm{NbOPO}_{4}$ (Hu et al., 2011; Sy et al., 2019; Fitriana et al., 2018) telah dikembangkan untuk aplikasi proses produksi biodiesel. Sayangnya, sintesis katalis heterogen yang sangat aktif bersifat kompleks, berbiaya mahal dan membutuhkan keterampilan khusus untuk tahap operasi produksi. Oleh karena itu, hal ini merupakan tantangan besar untuk mengeksplorasi katalis basa padat ideal yang efektif, murah, dan ramah lingkungan untuk dapat digunakan dalam proses produksi biodiesel sangat prospektif (Endut et al., 2017).

Untuk mengatasi masalah tersebut, pemanfaatan garam kalium karbonat $\left(\mathrm{K}_{2} \mathrm{CO}_{3}\right)$ komersial yang dapat disubstitusi dengan karbon aktif dari sekam padi sebagai katalis padat menjadi pilihan baru sebagai alternatif untuk produksi biodiesel dari minyak kemiri sunan. Pada tahun 2019, group ini telah melakukan reaksi transesterifikasi minyak kemangi menjadi biodiesel dengan menggunakan katalis $\mathrm{CaO}$ dari cangkang kerang yang dikalsinasi pada suhu $800 \quad{ }^{\circ} \mathrm{C}$. Penelitian menunjukkan bahwa yield biodiesel mencapai 96,7\% di bawah kondisi reaksi optimal dengan konsentrasi katalis dan waktu reaksi masing-masing $6 \%$ berat dan 3 jam (Zaki et al., 2019).

Pada penelitian ini, $\mathrm{K}_{2} \mathrm{CO}_{3}$ dideposisi pada permukaan karbon aktif dari limbah sekam padi merupakan solusi yang tepat untuk memperoleh katalis padat untuk reaksi transesterifikasi minyak nabati proses heterogen. Karbon aktif sangat efisien digunakan sebagai penyangga katalis karena memiliki luas permukaan yang tinggi (Asnawi et al., 2019). Selain itu, bahan baku sekam padi juga tersedia melimpah di daerah Aceh maupun Indonesia. Di Aceh, misalnya, diperkirakan produksi tahunan sekam padi lebih dari 5 juta ton pada tahun 2018 .

Dewasa ini, sebagian besar limbah sekam padi hanya dibakar dan dibuang ke ladang tanpa perlakuan awal. Dalam jumlah kecil, sekam padi telah dikonversi menjadi karbon aktif sebagai adsorben berbiaya rendah untuk mengekstraksi ion logam dalam limbah (Maliki et al., 2019). Komposisi organik arang sekam padi terutama terdiri dari karbon sekitar 95\%, yang dapat digunakan sebagai pengangga $\mathrm{K}_{2} \mathrm{O}$. Senyawa $\mathrm{K}_{2} \mathrm{CO}_{3}$ yang dipadu pada permukaan karbon aktif sekam padi dapat diubah menjadi $\mathrm{K}_{2} \mathrm{O} / \mathrm{C}$ sebagai fasa aktif setelah proses kalsinasi pada suhu $300{ }^{\circ} \mathrm{C}$. Oleh karena itu, $\mathrm{K}_{2} \mathrm{O} / \mathrm{C}$ dimungkinkan untuk digunakan sebagai katalis padat berbiaya rendah untuk proses produksi biodiesel. Belum banyak literatur yang melaporkan tentang katalis padat kalium oksida yang disangga pada karbon dari limbah sekam padi $\left(\mathrm{K}_{2} \mathrm{O} / \mathrm{C}\right)$.

Bahan baku minyak yang digunakan dalam penelitian ini adalah minyak kemiri sunan (Reutealis trisperma), seperti pada Gambar 1. Reutealis trisperma telah diakui memiliki potensi besar untuk produksi biodiesel karena minyaknya mengandung racun, sehingga tidak dapat digunakan sebagai minyak makan atau pangan lainnya. Kandungan minyak kemiri sunan mencapai $45-55 \%$ dari biji, memiliki bilangan asam 2,4-6,3 mg KOH/g minyak.

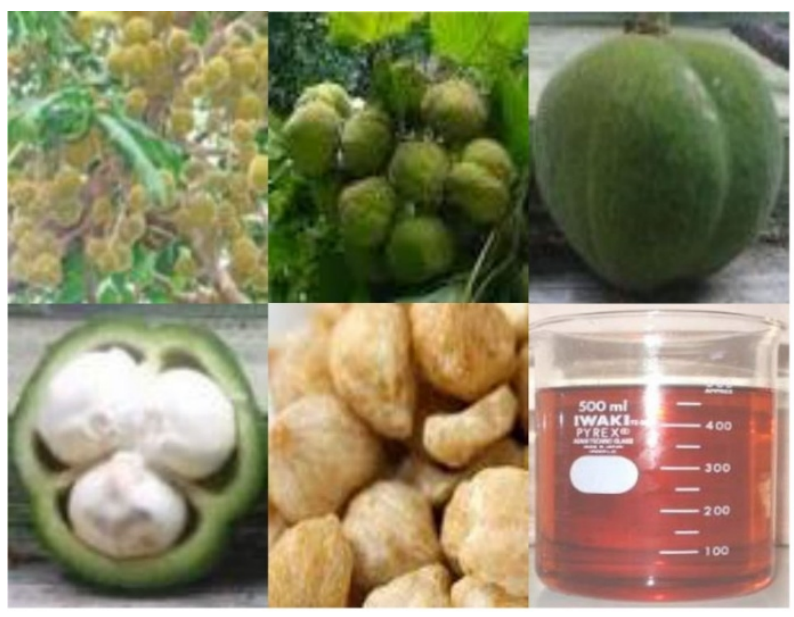

Gambar 1. Buah, biji, dan minyak kemiri sunan

Komposisi minyak kemiri sunan terdiri dari: asam miristat, asam palmitat, asam stearat, asam oleat, asam 
linoleat, asam linolenat dan jejak asam lainnya. Kandungan asam tertinggi adalah asam palmitat $(16,93 \%)$, oleat $(38,63 \%)$ dan linoleat $(35,06 \%)$ (Ritonga and Giovani, 2016).

Penelitian ini bertujuan untuk mengeksplorasi efektivitas penggunaan katalis padat $\mathrm{K}_{2} \mathrm{O} / \mathrm{C}$ pada proses katalitik produksi biodiesel dari minyak kemiri sunan. Katalis dianalisis menggunakan SEM dan EDX untuk mengkarakterisasi struktur mikro dan komposisi katalis. Kinerja katalitik dievaluasi melalui reaksi transesterifikasi minyak kemiri sunan dan metanol. Pengaruh variabel loading $\mathrm{K}_{2} \mathrm{CO}_{3}$ dan jumlah perulangan penggunan katalis terhadap yield biodiesel telah diselidiki.

\section{Metodelogi}

\subsection{Waktu, tempat, bahan dan peralatan}

Penelitian ini dilakukan sejak bulan Januari sampai April 2020. Kegiatan utama penelitian dilaksanakan di Laboratorium Teknik Reaksi Kimia dan Katalisis, Jurusan Teknik Kimia, Universitas Syiah Kuala, Banda Aceh, Indonesia.

Sekam padi diperoleh dari limbah penggilingan padi kilang padi di Kabupaten Aceh Besar. Bahan-bahan kimia: $\mathrm{K}_{2} \mathrm{CO}_{3}$, metanol 99,5\%, asam fosfat, HCL 37\%, $\mathrm{NaOH}$, phenolphtalein, dan air demineralizer dibeli dari PT Gemilang Sukses, Medan, Sumatera Utara Indonesia. Semua reagent bahan kimia memiliki grade dari Merck, Jerman. Sekam padi sebelum digunakan diaktifkan terlebih dahulu menjadi karbon aktif.

Penelitian ini menggunakan beberapa alat antara lain: labu leher-3 dan acsessories, hot plate, labu pemisah, corong pemisah, oven pemanas, $\mathrm{pH}$ meter, termometer, dan seperangkat alat gelas penunjang penelitian. Minyak kemiri sunan diperoleh dari Perusahaan perkebunan kemiri sunan di Bogor, Indonesia. Minyak kemiri sunan memiliki bilangan asam 2,4 $\mathrm{mgKOH} / \mathrm{g}$. Sebelum digunakan minyak diesterifikasi terlebih dahulu untuk menurunkan bilangan asam hingga lebih kecil dari $1 \%$.

\subsection{Preparasi karbon aktif sekam padi}

Mekanisme preparasi katalis $\mathrm{K}_{2} \mathrm{O}$ pada karbon aktif sekam padi seperti ditampilkan pada Gambar 2.

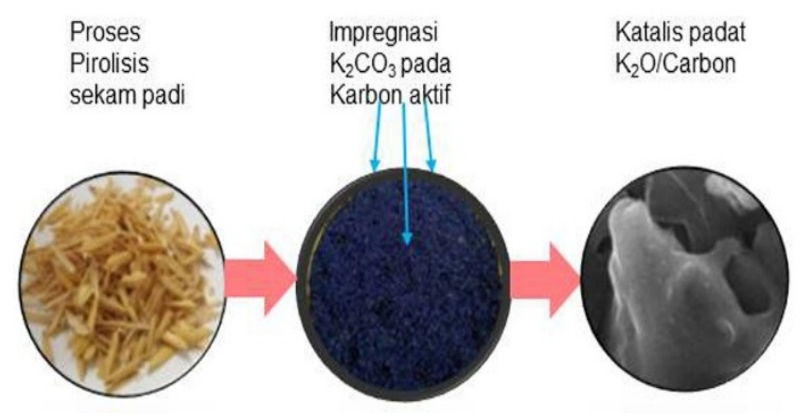

Gambar 2. Skematik preparasi katalis $\mathrm{K}_{2} \mathrm{O}$ pada karbon aktif sekam padi

Tahap pertama, sekam padi dicuci untuk menghilangkan kotoran yang tersisa. Selanjutnya, sekam padi dikeringkan dalam oven selama 24 jam pada suhu
$80{ }^{\circ} \mathrm{C}$ untuk mengurangi kadar air. Sekam padi yang telah kering dipirolisis pada $400{ }^{\circ} \mathrm{C}$ selama 30 menit untuk proses karbonisasi. Kemudian karbon dipirolisis lanjut pada $650{ }^{\circ} \mathrm{C}$ selama 1,5 jam untuk proses aktivasi. Karbon aktif sekam padi dihancurkan menjadi 20-80 mesh untuk mendapatkan ukuran yang seragam (Maliki et al., 2019). Karbon aktif selanjutnya digunakan sebagai penyangga $\mathrm{K}_{2} \mathrm{O}$ sebagai fasa aktif katalis $\mathrm{K}_{2} \mathrm{O} / \mathrm{C}$.

\subsection{Preparasi katalis $\mathrm{K}_{2} \mathrm{O} / \mathrm{C}$}

Katalis padat $\mathrm{K}_{2} \mathrm{O} / \mathrm{C}$ disiapkan dengan metode impregnasi. Sumber kalium digunakan senyawa $\mathrm{K}_{2} \mathrm{CO}_{3}$ komersial. Rasio berat $\mathrm{K}_{2} \mathrm{CO}_{3}$ terhadap karbon sekam padi (C) divariasi, yaitu: 0,$1 ; 0,2 ; 0.3 ; 0.4 ; 0.5$ dan 0,6 Senyawa $\mathrm{K}_{2} \mathrm{CO}_{3}$ dilarutkan dalam beaker glass berisi air demineralizer hingga larut. Larutan dicampur dengan karbon sekam padi selama 6 jam pada suhu kamar. Campuran selanjutnya dipanaskan dalam oven selama 12 jam. Powder selanjutnya dikalsinasi pada suhu 300 ${ }^{\circ} \mathrm{C}$ selama 3 jam untuk penyusunan fasa aktif dan stabilitas mekanik (Hasfita and Husin, 2013; Mardian et al., 2018). Setelah didinginkan, katalis disimpan dalam desikator.

\subsection{Karakterisasi katalis}

Untuk mendeteksi morfologi dan komponen kimia katalis, sebagian sampel dilakukan karakterisasi. Identifikasi morfologi $\mathrm{K}_{2} \mathrm{O} / \mathrm{C}$ menggunakan metode Scanning Electron Microscopy, SEM (Model JSM$6700 \mathrm{~F}$, JEOL). Sedangkan untuk mengkonfirmasi komponen kimia katalis dilakukan dengan metode Energy Dispersive X-Ray Spectroscopy (EDX). Pengukuran SEM dan EDX dilakukan di Laboratorium SEM Polri Jakarta.

\subsection{Reaksi transesterifikasi minyak kemiri sunan menjadi biodiesel}

Reaksi transesterifikasi minyak kemiri sunan dan metanol menggunakan katalis berbasis kalium yang disangga pada karbon aktif $\left(\mathrm{K}_{2} \mathrm{O} / \mathrm{C}\right)$. Minyak kemiri sunan $50 \mathrm{~g}$ dan katalis sebanyak 4\% dari berat minyak dimasukkan ke dalam reaktor batch. Reaktor dilengkapi dengan kondensor untuk menghindari penguapan metanol selama proses reaksi. Rasio molar metanolminyak 8:1 dan suhu tetap pada $65^{\circ} \mathrm{C}$. Setelah diaduk selama 1,5 jam, reaksi transesterifikasi dihentikan. Katalis dipisahkan dari campuran dengan sentrifugasi selama 0,5 jam. Campuran reaksi dipindahkan ke corong pisah dan dicuci dengan air panas, yang memungkinkan dekantasi dan pemisahan gliserol dan metil ester. Selanjutnya, metil ester dipindahkan ke rotary vacuum evaporator untuk menghilangkan metanol yang tersisa. Metil ester dikeringkan pada $110{ }^{\circ} \mathrm{C}$ dalam oven untuk menghilangkan kandungan air. Perolehan (Yield) biodiesel dihitung menurut Persamaan berikut.

Yield (\%) $=\frac{\text { berat biodiesel }}{\text { berat minyak yang digunakan }} \times 100 \%$ 


\section{Hasil dan Pembahasan}

\subsection{Hasil karakterisasi SEM dan EDX}

Untuk mendapatkan gambaran tentang morfologi sampel katalis $\mathrm{K}_{2} \mathrm{O} / \mathrm{C}$ hasil preparasi, studi SEM dilakukan seperti yang tampak pada Gambar 3. Dari Gambar 3 tampak bahwa struktur permukaan karbon aktif sekam padi memiliki pori. Demikian juga, fasa aktif $\mathrm{K}_{2} \mathrm{O}$ terdistribusi sempurna pada permukaan pori karbon aktif sekam padi.

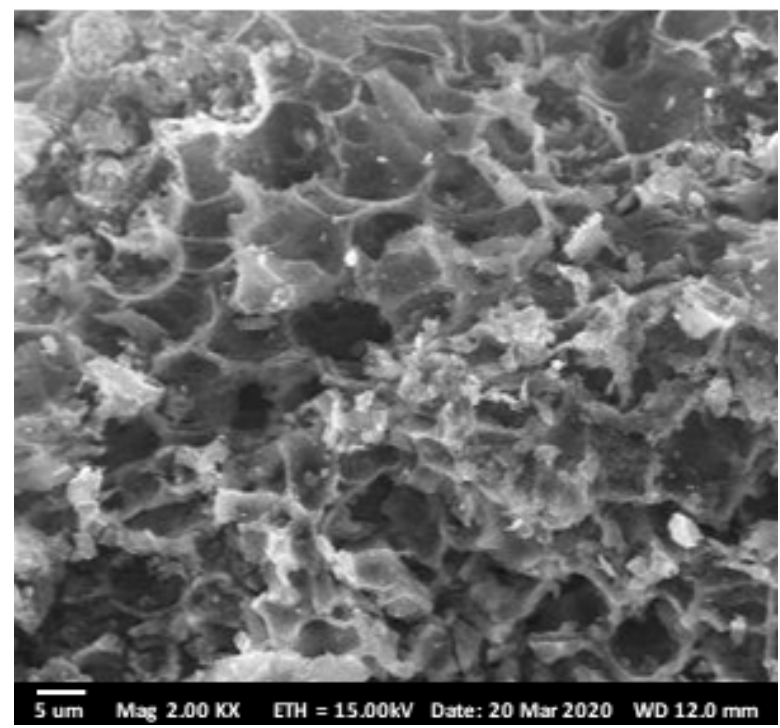

Gambar 3. Hasil rekaman SEM katalis padat $\mathrm{K}_{2} \mathrm{O} / \mathrm{C}$

Adanya fasa aktif $\mathrm{K}_{2} \mathrm{O}$ pada permukaan karbon aktif akan berkontribusi mempercepat jalannya proses reaksi katalitik transesterifikasi minyak kemiri sunan menjadi biodiesel, seperti yang dilaporkan pada penelitian sebelumnya (Husin et al., 2018c).

Tabel 1.

Komposisi atom dari senyawa-senyawa yang terkandung pada katalis $\mathrm{K}_{2} \mathrm{O} / \mathrm{C}$ dari analisa $\mathrm{EDX}^{*}$ )

\begin{tabular}{lll}
\hline Elemen & $\begin{array}{l}\text { Persen senyawa } \\
\text { wt. } \%\end{array}$ & $\begin{array}{l}\text { Persen atom } \\
\%\end{array}$ \\
\hline Carbon & 27,66 & 44,99 \\
Oksigen & 34,13 & 41,66 \\
Natrium & 0,44 & 0,37 \\
Silika & 2,76 & 2,06 \\
Kalium & 21,86 & 10.92 \\
\hline Total & 86,87 & 100,00 \\
\hline
\end{tabular}

${ }^{*}$ Hasil Analisa dengan EDX

Tabel 1 menyajikan informasi tentang komposisi atom katalis $\mathrm{K}_{2} \mathrm{O} / \mathrm{C}$. Dari hasil analisa Energy Diffraction X-ray (EDX),. Dari Tabel 1 terkonfirmasi bahwa komposisi katalis terdiri dari C (44,99\%), O (41,46\%), Na (0,37\%), Si (2,06\%) dan K (10,92\%). Hasil ini membuktikan bahwa komponen $\mathrm{K}_{2} \mathrm{O}$ telah terbentuk pada katalis seperti yang diinginkan. Dengan adanya fasa aktif $\mathrm{K}_{2} \mathrm{O}$ diharapkan dapat berkontribusi dalam mempercepat proses reaksi.

\subsection{Hasil uji kinerja katalis 3.2.1 Pengaruh pemuatan $\mathrm{K}_{2} \mathrm{CO}_{3}$ pada karbon aktif}

Pengaruh muatan $\mathrm{K}_{2} \mathrm{O}$ pada karbon aktif merupakan tahap krusial dari reaksi transesterifikasi minyak kemiri sunan. Hubungan rasio pemuatan $\mathrm{K}_{2} \mathrm{CO}_{3}$ pada karbon aktif terhadap yield metil ester (biodiesel) seperti didemonstrasikan pada Gambar 4.

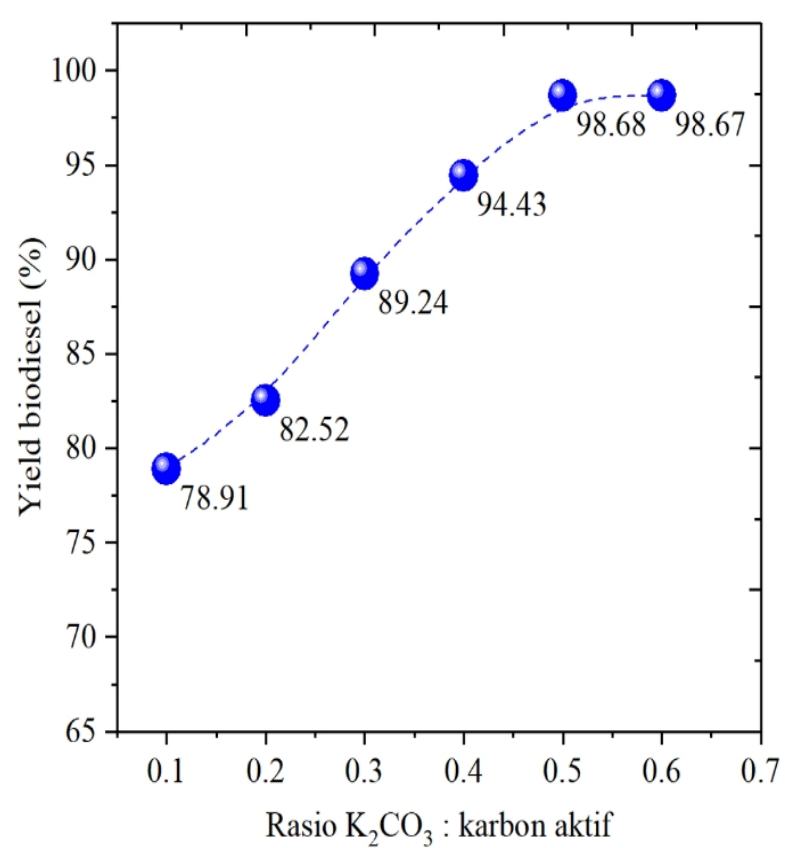

Gambar 4. Pengaruh rasio massa $\mathrm{K}_{2} \mathrm{CO}_{3}$ terhadap $\mathrm{C}$ terhadap yield metil ester. Kondisi reaksi: rasio molar minyak ; metanol 8:1, katalis $4 \%$ berat terhadap minyak, suhu reaksi $65{ }^{\circ} \mathrm{C}$, dan waktu reaksi 1,5 jam.

Berdasarkan Gambar 4, dapat dilihat bahwa yield metil ester meningkat secara proporsional dengan peningkatan pemuatan $\mathrm{K}_{2} \mathrm{CO}_{3}$ pada karbon aktif. Pada perbandingan berat $\mathrm{K}_{2} \mathrm{CO}_{3}$ terhadap karbon 0,1 yield metil ester mencapai 78,91\%. Yield metil ester tertinggi diperoleh $96,68 \%$ pada loading $\mathrm{K}_{2} \mathrm{CO}_{3}$ sebanyak 0,5. Penambahan $\mathrm{K}_{2} \mathrm{CO}_{3}$ lebih lanjut tampak kenaikan metil ester hampir sama. Fakta ini mengisyaratkan bahwa jumlah $\mathrm{K}_{2} \mathrm{CO}_{3}$ yang dimuat mempengaruhi jumlah situs aktif $\mathrm{K}_{2} \mathrm{O}$ yang terbentuk pada permukaan karbon aktif. Keberadaan situs aktif $\mathrm{K}_{2} \mathrm{O}$ mempengaruhi laju konversi trigliserida menjadi metil ester. Lebih lanjut komponen $\mathrm{K}_{2} \mathrm{O}$, selain berfungsi sebagai tempat terjadinya reaksi juga berperan meningkatkan sifat mekanik dan selektivitas katalis (Nurhazanah et al., 2020; Yani et al., 2019).

\subsubsection{Uji stabilitas katalis}

Penelitian tentang reaksi transesterifikasi minyak kemiri Sunan pada katalis $\mathrm{K}_{2} \mathrm{O} / \mathrm{C}$ telah berhasil dilakukan. Reaksi berlangsung pada kondisi reaksi: suhu reaksi $65{ }^{\circ} \mathrm{C}$, rasio molar minyak terhadap metanol 8:1, katalis $4,0 \%$ dari berat minyak, dan waktu reaksi 1,5 jam. Campuran reaksi disentrifugasi dan katalis dipisahkan tanpa pencucian. Selanjutnya katalis diaktivasi dalam furnace pada suhu $500{ }^{\circ} \mathrm{C}$ selama 2 jam 
dengan dialirkan $\mathrm{N}_{2}$ untuk menghilangkan gliserol yang teradsorpsi.

Gambar 5 menampilkan penggunaan kembali katalis dalam reaksi transesterifikasi minyak kemiri sunan dengan metanol. Terungkap bahwa hasil biodiesel menurun sedikit setelah empat kali berjalan dengan hasil biodiesel 87,23\%.

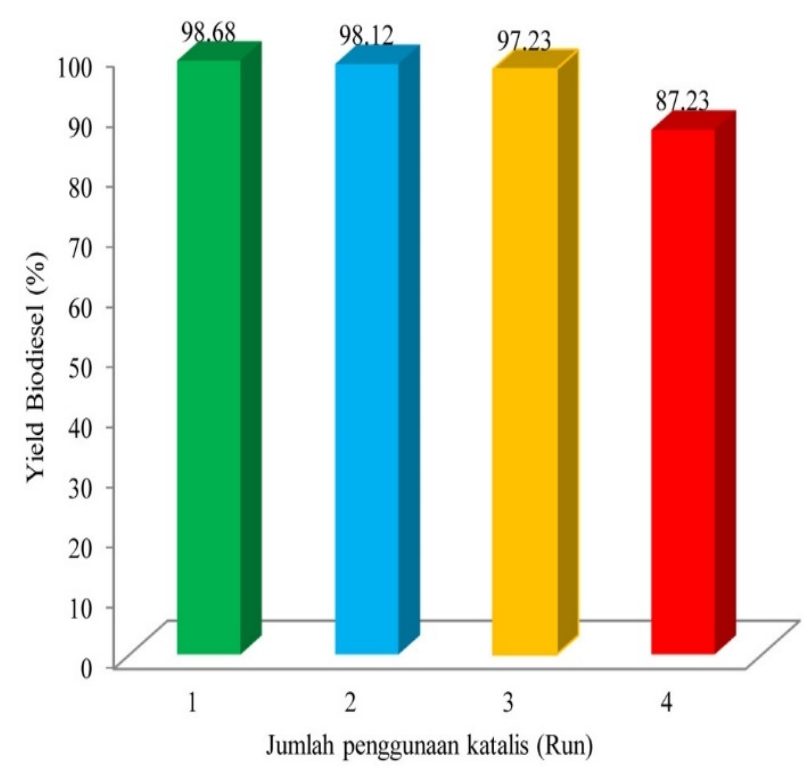

Gambar 5. Jumlah penggunaan katalis terhadap Yield biodiesel

Penurunan aktivitas katalitik setelah daur ulang keempat diduga karena beberapa alasan. Alasan pertama, kemungkinan jumlah katalis sedikit berkurang selama proses pemisahan. Penyebab lainnya, setelah penggunaan katalis secara berulang kali, kemungkinan morfologinya juga berubah, misalnya, terjadi agregasi partikel, lepasnya situs aktif $\mathrm{K}_{2} \mathrm{O}$ dari permukaan karbon. Fenomena ini berakibat pada menurunnya kinerja katalis (Abdullah et al., 2017a; Thushari et al., 2019).

\subsection{Sifat kimia dan fisika Biodiesel}

Tabel 2 menyajikan perbandingan karakteristik kimia dan fisika biodiesel yang diperoleh dengan standar ASTM dan SNI.

Table 2.

Sifat-sifat kimia dan fisika biodiesel

\begin{tabular}{lccc}
\hline Elemen & $\begin{array}{c}\text { Hasil } \\
\text { penelitian }\end{array}$ & ASTM & SNI \\
\hline $\begin{array}{l}\text { Densitas } \\
\left(\mathrm{gr} / \mathrm{cm}^{3}\right)\end{array}$ & $0.85-0,87$ & $0,80-0,88$ & $0.85-0.89$ \\
$\begin{array}{l}\text { Viscositas } \\
\begin{array}{l}\text { Kinematik } \\
(\mathrm{cSt})\end{array}\end{array}$ & $2.5-3.5$ & $2.59-3.4$ & $2.30-6,00$ \\
$\begin{array}{l}\text { Bilangan asam } \\
(\mathrm{mg} \mathrm{KOH} / \mathrm{gr})\end{array}$ & $0.12-0.42$ & $\max 0.80$ & $\max 0.80$ \\
${ }^{\mathrm{a}}$ Based on SNI 7182:2015 & & \\
\hline
\end{tabular}

Dari data dalam Tabel 2 dapat dilihat bahwa perbandingan sifat kimia dan fisika biodiesel yang diperoleh dengan standar ASTM dan SNI. Seperti dapat dilihat, karakteristik biodiesel yang dihasilkan memenuhi batas standar ASTM maupun SNI. Jadi, sifat-sifat biodiesel yang diperoleh dari minyak kemiri sunan dinilai dapat dijadikan sebagai bahan bakar yang prospektif sebagai biodiesel komersial alternatif.

\section{Kesimpulan}

Katalis $\mathrm{K}_{2} \mathrm{O} / \mathrm{C}$ untuk reaksi transesterifikasi telah berhasil dibuat dengan sempurna. Komposisi $\mathrm{K}_{2} \mathrm{O}$ terdistribusi secara merata pada permukaan pori karbon aktif. Keberadaan $\mathrm{K}_{2} \mathrm{O}$ pada karbon aktif juga teridentifikasi dari hasil analisa $E D X . \quad \mathrm{K}_{2} \mathrm{O}$ berfungsi sebagai fasa aktif memiliki kemampuan meningkatkan aktivitas katalis pada konversi minyak kemiri sunan menjadi biodiesel. Deposisi kalium oksida pada karbon menghasilkan interaksi yang sangat baik antara fasa aktif dengan penyangga karbon, sehingga katalis memiliki aktivitas yang tinggi. Perolehan biodiesel tertinggi dicapai $98,68 \%$, pada loading $\mathrm{K}_{2} \mathrm{CO}_{3} 0,5$, berat katalis terhadap minyak sebanyak $4 \%$ berat. Karakteristik biodiesel hasil penelitian sesuai dengan standar SNI maupun ASTM.

\section{Ucapan terima kasih}

Penulis mengucapkan terima kasih kepada Rektor Universitas Syiah Kuala, Darussalam, Banda Aceh atas bantuan dana melalui Hibah Penelitian Lektor sehingga penelitian ini dilaksanakan.

\section{Daftar Pustaka}

Abdullah, Rahmawati Sianipar, R. N., Ariyani, D. \& Nata, I. F. 2017a. Conversion of palm oil sludge to biodiesel using alum and $\mathrm{KOH}$ as catalysts. Sustainable Environment Research, 27, 291-295.

Abdullah, S. H. Y. S., Hanapi, N. H. M., Azid, A., Umar, R., Juahir, H., Khatoon, H. \& Endut, A. 2017b. A review of biomass-derived heterogeneous catalyst for a sustainable biodiesel production. Renewable And Sustainable Energy Reviews, 70, 1040-1051.

Abedin, M. J., Kalam, M. A., Masjuki, H. H., Sabri, M. F. M., Rahman, S. M. A., Sanjid, A. \& Fattah, I. M. R. 2016. Production of biodiesel from a non-edible source and study of its combustion, and emission characteristics: A Comparative Study With B5. Renewable Energy, 88, 20-29.

Aboelazayem, O., El-Gendy, N. S., Abdel-Rehim, A. A., Ashour, F. \& Sadek, M. A. 2018. Biodiesel production from castor oil in egypt: process optimisation, kinetic study, diesel engine performance and exhaust emissions analysis. Energy, 157, 843-852.

Asnawi, T. M., Husin, H., Adisalamun, A., Rinaldi, W., Zaki, M. \& Hasfita, F. 2019. Activated carbons from palm kernels shells prepared by physical and chemical activation for copper removal from aqueous solution. Iop Conference Series: Materials Science And Engineering, 543, 012096. 
Boonyuen, S., Smith, S. M., Malaithong, M., Prokaew, A., Cherdhirunkorn, B. \& Luengnaruemitchai, A. 2018. Biodiesel production by a renewable catalyst from calcined turbo jourdani (Gastropoda: Turbinidae) shells. Journal of Cleaner Production, 177, 925-929.

Borges, M. E. \& Díaz, L. 2012. Recent developments on heterogeneous catalysts for biodiesel production by oil esterification and transesterification reactions: a review. Renewable And Sustainable Energy Reviews, 16, 2839-2849.

Endut, A., Abdullah, S. H. Y. S., Hanapi, N. H. M., Hamid, S. H. A., Lananan, F., Kamarudin, M. K. A., Umar, R., Juahir, H. \& Khatoon, H. 2017. Optimization of biodiesel production by solid acid catalyst derived from coconut shell via response surface methodology. International Biodeterioration \& Biodegradation, 124, 250-257.

Farooq, M., Ramli, A., Naeem, A., Mahmood, T., Ahmad, S., Humayun, M. \& Islam, M. G. U. 2018. Biodiesel production from date seed oil (Phoenix Dactylifera L.) via egg shell derived heterogeneous catalyst. Chemical Engineering Research and Design, 132, 644-651.

Fitriana, N., Husin, H., Yanti, D., Pontas, K., Alam, P. N., Ridho, M. \& Iskandar 2018. Synthesis of K ${ }_{2} \mathrm{O} /$ Zeolite catalysts by koh impregnation for biodiesel production from waste frying oil. IOP Conference Series: Materials Science And Engineering, 334, 012011.

Granados, M. L., Poves, M. D. Z., Alonso, D. M., Mariscal, R., Galisteo, F. C., Moreno-Tost, R., Santamaría, J. \& Fierro, J. L. G. 2007. Biodiesel from sunflower oil by using activated calcium oxide. Applied Catalysis B: Environmental, 73, 317-326.

Hasfita, F. \& Husin, H. 2013. Pengaruh temperatur reaksi terhadap aktivitas katalis besi molibdenum oksida berpromotor kromium oksida. Malikussaleh Industrial Engineering Journal, 2, 24-28.

Hu, S., Wang, Y. \& Han, H. 2011. Utilization of waste freshwater mussel shell as an economic catalyst for biodiesel production. Biomass And Bioenergy, 35, 3627-3635.

Husin, H., Abubakar, A., Ramadhani, S., Sijabat, C. F. B. \& Hasfita, F. 2018a. Coconut Husk Ash As Heterogenous Catalyst For biodiesel production from cerbera manghas seed oil. Matec Web of Conference, 197, 09008.

Husin, H., Asnawi, T. M., Alam, P. N. \& Hasfita, F. 2018 b. Enhanced photocatalytic hydrogen production from water-ethanol solution by ruthenium doped La$\mathrm{NaTO}_{3}$. IOP Conf. Series: Materials Science And Engineering, 345

Husin, H., Asnawi, T. M., Firdaus, A., Husaini, H., Ibrahim, I. \& Hasfita, F. 2018c. Solid catalyst nanoparticles derived from oil-palm empty fruit bunches (Op-Efb) as a renewable catalyst for biodiesel production. IOP Conference Series: Materials Science And Engineering, 358, 012008.

Husin, H., Hasfita, F. \& Rinaldi, W. Waste shells of cockle (clinocardium nuttalli) as solid catalysts for transesterification of Calophyllum Inophyllum L. oil to biodiesel production. Proceedings of The Annual International Conference, Syiah Kuala UniversityLife Sciences \& Engineering Chapter, 2013. 14-18.

Islam, A., Taufiq-Yap, Y. H., Ravindra, P., Teo, S. H., Sivasangar, S. \& Chan, E.-S. 2015. Biodiesel synthesis over millimetric $\Gamma-\mathrm{Al}_{2} \mathrm{O}_{3} / \mathrm{Ki}$ Catalyst. Energy, 89, 965-973.

Li, X. F., Zuo, Y., Zhang, Y., Fu, Y. \& Guo, Q.-X. 2013. In situ preparation of $\mathrm{K}_{2} \mathrm{CO}_{3}$ supported kraft lignin activated carbon as solid base catalyst for biodiesel production. Fuel, 113, 435-442.

Liu, H., Su, L., Liu, F., Li, C. \& Solomon, U. U. 2011 Cinder supported $\mathrm{k}_{2} \mathrm{CO}_{3}$ as catalyst for biodiesel production. Applied Catalysis B: Environmental, 106, 550-558.

Maliki, S., Rosnelly, C. M., Adisalamun, A., Husin, H. \& Bilqis, N. 2019. Removal of Fe (Ii) in groundwater using rice husk-sourced biosorbent in continuous column adsorption. Journal Of Physics: Conference Series, 1402, 055007.

Mardian, R., Husin, H., Pontas, K., Zaki, M., Asnawi, T. M. \& Ahmadi 2018. Hydrogen production from water-glucose solution over $\mathrm{NiO} / \mathrm{La}-\mathrm{NaTaO}_{3}$ photocatalyst. Iop Conference Series: Materials Science And Engineering, 334, 012013.

Nurhazanah, N., Sy, Y., Husin, H., Rosnelly, C. M. \& Maulana, A. 2020. K2o/Nbopo4 solid acid catalyst for biodiesel Production. IOP Conference Series: Materials Science And Engineering, 796, 012048.

Ong, H. C., Milano, J., Silitonga, A. S., Hassan, M. H., Shamsuddin, A. H., Wang, C.-T., Indra Mahlia, T. M., Siswantoro, J., Kusumo, F. \& Sutrisno, J. 2019. Biodiesel production from calophyllum inophyllumceiba pentandra oil mixture: optimization and characterization. Journal of Cleaner Production, 219, 183-198.

Ritonga, M. Y. \& Giovani, M. R. R. 2016. Pembuatan metil ester dari minyak kemiri sunan dengan keberadaan co-solvent aseton dan katalis heterogen natrium silikat terkalsinasi. Teknik Kimia Usu, 5, 1723.

Sy, Y., Nurhazanah, N., Maulana, A., Mahidin, M. \& Husin, H. 2019. Study of $\mathrm{pH}$ influences on the performance of Na-Loaded $\mathrm{NbOPO}_{4}$ solid acid catalyst for biofuel production. Journal of Physics: Conference Series, 1402, 055006.

Thushari, I., Babel, S. \& Samart, C. 2019. Biodiesel production in an autoclave reactor using waste palm oil and coconut coir husk derived catalyst. Renewable Energy, 134, 125-134.

Yani, F. T., Ulhaqi, R., Pratiwi, W. P., Pontas, K. \& Husin, H. 2019. Utilization of water hyacinth-based biomass as a potential heterogeneous catalyst for biodiesel production. Journal of Physics: Conference Series, 1402, 055005.

Zaki, M., Husin, H., Alam, P. N., Darmadi, Rosnelly, C. M. \& Nurhazanah 2019. Transesterifikasi minyak biji buta-buta menjadi biodiesel pada katalis heterogen kalsium oksida (CaO). Jurnal Rekayasa Kimia \& Lingkungan, 14, 36-43. 